\title{
LCK Gene Mutation
}

National Cancer Institute

\section{Source}

National Cancer Institute. LCK Gene Mutation. NCI Thesaurus. Code C133689.

A change in the nucleotide sequence of the LCK gene. 